\title{
Fair or Fraud: has the Protocol Amending TRIPS FLOURISHED OR FAILED?
}

\author{
SIOBHÁN ELIZABETH STADE MURILLO ${ }^{1}$
}

\section{INTRODUCTION}

Global health has been a central concern in both the domestic and international community for years. Infectious diseases, such as HIV/AIDS, malaria, and tuberculosis kill over 10 million people each year - and over $90 \%$ of those killed live in the developing world, ${ }^{2}$ meaning, parts of the world that are less economically and technologically advanced. Despite various efforts, many obstacles continue to frustrate attempts to attain fair health standards across the world. One obstacle in the fight against rising epidemics is the inadequate access to essential medicines in low and middle-income countries. There are many factors that contribute to a country being qualified as a low- or middle-income country, including government spending on health care. For instance, government allocations can range from less than $5 \%$ in some African countries, making those countries low-income, compared to over $20 \%$ in America. ${ }^{3}$ There are many factors that contribute to a low rate of access, but the primary cause is the price of drugs.

The Trade-Related Intellectual Property Rights (TRIPS) agreement binds the approximately 160 nations that are members to the World Trade Organization. ${ }^{4}$ Congress ratified and implemented the TRIPS agreement in the United States in 1995. In 2001, the World Trade Organization approved the Doha Declaration on TRIPS and Public Health. ${ }^{6}$ The purposes of this declaration was to reduce ambiguities relating to the licensing provisions of TRIPS and to affirm the right of countries to prioritize access to medicines and public health over intellectual property rights. ${ }^{7}$ The Doha Declaration would allow for access to essential medicines while simultaneously lessening patent restrictions and thus lowering the price for these essential medicines. ${ }^{8}$

1. Siobhán Elizabeth Stade Murillo is a practicing attorney in San Diego, California. She is a 2016 graduate of the University of San Diego School of Law, where she received her J.D. In 2013, she received her B.A. in Political Science/Public Law, cum laude, from the University of California, San Diego.

2. Ellen F. M. Hoen, TRIPS, Pharmaceutical Patents and Access to Essential Medicines: Seattle, Doha, and Beyond, 3 Chi. J. of Intl' L. 27, 40 (2003).

3. See World Health Organization, World Health Statistics 2006, at 16 (2006), available at http://www.who.int/whosis/whostat2006.pdf.

4. Ralph H. Folsom, Principles of International Trade LaW InCluding THE World Trade Organization, NAFTA AND the European Union 31 (2014).

5. Id.

6. Africa: Health, Patents Clash, Africafocus, Dec. 6, 2005, http://www. africafocus.org/docs05/trip0512.php.

7. $I d$.

8. Id. 
In 2003, two years after the Doha Declaration, there was yet another Protocol amending the TRIPS Agreement, the TRIPS Public Health Amendment. ${ }^{9}$ The purpose of the TRIPS Public Health Amendment is to provide cheaper versions of patented medicines to underdeveloped countries that may not otherwise be able to afford necessary medicines to combat epidemics, such as HIV/AIDS and malaria. However, a major issue with TRIPS is that it did not address how countries with insufficient manufacturing capacity, including India, South Africa, and Thailand, could make use of such rights and the TRIPS Public Health Amendment has been more detrimental than successful in achieving this goal in these countries. ${ }^{10}$ As such, access to essential life-saving generic drugs, such as those used to treat HIV/AIDS, remains unavailable in underdeveloped and developing countries.

While the TRIPS Public Health Amendment is commendable, it has been hit with immense criticism. Critics argue that not only is the amendment controversial, but it often goes unimplemented and thus fails its established purpose. The question remains: has the TRIPS Public Health Amendment truly flourished or simply failed?

\section{THE TRIPS AGREEMENT}

The General Agreement on Tariffs and Trade, otherwise known as GATT, was established in 1947. ${ }^{11}$ GATT was an international arrangement with over 100 countries that sought to open up international trade. ${ }^{12}$ Some successes of GATT include reducing tariff costs and eliminating some tariffs entirely. ${ }^{13}$ GATT became the basis for the establishment of the World Trade Organization (WTO), which eventually replaced GATT. ${ }^{14}$

The WTO is the product of the Uruguay Round of GATT negotiations, which were completed in $1994 .^{15}$ The creators of the WTO specifically designed it to fix many of GATT's shortcomings. ${ }^{16}$ It is essentially an organization that supervises and liberalizes international trade. ${ }^{17}$ Thus, the WTO was created as a unified system for all of the Uruguay Round Agreements to come under. ${ }^{18}$ However, the WTO does not change the scope of GATT and is guided by the decisions and

9. See World Trade Organization, Amendment to the Agreement on Trade-Related Aspects of Intellectual Property Rights (TRIPS), available at https://www.wto.org/english/ tratop_e/trips_e/tripsfacsheet_e.htm.

10. Africa: Health, supra note 6.

11. Folsom, supra note 4 , at 7.

12. Id at 6 .

13. Id.

14. Thomas J. Dillon, Jr., The World Trade Organization: A New Legal Order For World Trade?, 16 Mich. J. INT'L. L. 349, 355 (1995).

15. Folsom, supra note 4, at 13.

16. Dillon, supra note 14 at 355.

17. Id at 350 .

18. Id. 
procedures of GATT. ${ }^{19}$ The WTO does not have any additional power than that "which existed for the GATT under the previous agreements." 20

TRIPS was negotiated at the end of the Uruguay Round of the GATT in 1994. ${ }^{21}$ While the TRIPS Agreement was adopted in Morocco in 1994, it was not put into effect until January 1, 1995. ${ }^{22}$ The TRIPS Agreement is a multilateral agreement under the WTO, which means that any country that wants to join the WTO must also agree to abide by the TRIPS Agreement. ${ }^{23}$

The purpose of the TRIPS Agreement is to provide adequate protection for intellectual property rights and to promote global competition. ${ }^{24}$ This means that any country seeking to obtain easy access to international markets opened by the WTO must enact the strict intellectual property rights that accompany TRIPS. TRIPS sought to reduce impediments to international trade and establish minimum intellectual property right (IPR) standards. ${ }^{25}$ It also required member states to extend patent life spans to twenty years and establish standards for "novelty and inventiveness." ${ }^{26}$ Greater IPR protections were one of the major facets of TRIPS and the United States' pharmaceutical industry was a major proponent of strengthening such protections. ${ }^{27}$ One reason for lobbying for greater IPR protection was so that pharmaceutical companies could "recoup their R\&D (research and development) costs." ${ }^{28}$ Another reason was that without such strong IPR protection, generic imitators would have the ability to "free-ride" on the brand name manufacturers" capabilities and would thus "chill technological innovation." 29

This leaves TRIPS member countries with two choices. First, the member country can buy medicines from the patent-holding United States corporation,

19. Id. at 356; see also, General Agreement on Tariffs and Trade: Multilateral Trade Negotiations Final Act Embodying The Results of The Uruguay Round of Trade Negotiations, 33 I.L.M. 1125,1152 (1994) ("the WTO shall be guided by the decisions, procedures and customary practices followed by the CONTRACTING PARTIES to GATT 1947 and the bodies established in the framework of GATT 1947").

20. Id.

21. Dillon, supra note 14 at 350.

22. Evelyn Su, The Winners and the Losers: The Agreement on Trade-Related Aspects of Intellectual Property Rights and Its Effects on Developing Countries, 23 Hous. J. INT'L L. 169, 185 (2000).

23. Id

24. Id. at 186 .

25. Timothy Bazzle, Pharmacy of the Developing World: Reconciling Intellectual Property Rights in India with the Right to Health: TRIPS, India's Patent System and Essential Medicines, 42 GEO. J. INT'L L. 785, 792 (2011).

26. Id.

27. Id. at 793 .

28. Id. (defining R\&D expenses as operating expenses that are incurred while finding and creating new products or services)(alteration in original).

29. Id. 
which is generally between 2.5 and 100 times the price of a generic version. ${ }^{30}$ Or under TRIPS, a member country can issue compulsory licenses and engage in parallel importation. ${ }^{31}$ Parallel importation is essentially a strategy to lower the costs of the brand-name drugs and compulsory licensing is a method of obtaining generic drugs at a lower cost by authorizing the sale of the generic version of an otherwise-patented medication. ${ }^{32}$ Pharmaceutical companies often oppose parallel importation because price discrimination is a profitable market strategy - and because they can make immense amounts of money by simply keeping generic drugs off the market, thus forcing member countries to buy the expensive, patentheld, brand name drugs. ${ }^{33}$

However, one criticism of TRIPS is the standard of requiring all countries to create such strict intellectual property systems, which is detrimental to poorer countries' development. ${ }^{34}$ Thus, many developing countries, which have adopted TRIPS, have not incorporated any flexibilities provided under TRIPS, such as compulsory licensing, to the extent authorized under Doha, because of the inherently strict standards required under TRIPS..$^{35}$ For instance, both India and Brazil have voiced their concerns over these stringent IPR protections. ${ }^{36}$ Their apprehension stems from the idea that because pharmaceutical firms have immense power to restrict the supply of medicines they produce, they would have the ability to enrich themselves while limiting the production of generic medicines, thus hurting the public that needs generic versions of essential medicines. ${ }^{37}$

\section{DOHA DECLARATION ON THE TRIPS AGREEMENT}

TRIPS was amended to include the Doha Declaration in 2001. The purpose of the WTO Ministerial Conference held in Doha, Qatar in November 2001 was to reduce ambiguities relating to the compulsory licensing provisions of TRIPS. ${ }^{38}$ The result of the meeting was a Declaration on the TRIPS Agreement and Public Health (the Doha Declaration). ${ }^{39}$ The 2001 Doha Declaration includes the

30. Margaret B. Kwoka, Vindicating the Rights of People Living with AIDS under the Alien Tort Claims Act, 40 Loy. U. Chi. L.J. 643, 645 (2009).

31. Id.

32. Id. at 657 .

33. $I d$.

34. Id. at 688 .

35. Sisule F. Musungu \& Cecilia Oh, The Use of Flexibilities in TRIPS by Developing Countries: Can They Promote Access to Medicines?, Commission on Intellectual Property Rights, Innovation and Public Health (CIPIH),(Aug. 2005), http://www.who.int/ intellectualproperty/studies/TRIPSFLEXI.pdf?ua=1.

36. Bazzle, supra note 25 , at 793.

37. Id. at 794 .

38. Divya Murthy, The Future of Compulsory Licensing: Deciphering the Doha Declaration on the TRIPS Agreement and Public Health, 17 AM. U. INT'L L. REV. 1299, 1304 (2002).

39. Id. 
following statement in part: “...we affirm that the Agreement can and should be interpreted and implemented in a manner supportive of WTO Members' right to protect public health, and, in particular, to promote access to medicines for all. ${ }^{~}{ }^{40}$ The 2005 amendment to TRIPS implements the Doha Declaration. ${ }^{41}$ Further, in paragraph 5, the Declaration defines flexibilities within TRIPS that can be used to overcome harsh intellectual property barriers to accessing essential medicines, such as HIV/AIDS, malaria, and tuberculosis medications. ${ }^{42}$

\section{POST-TRIPS EXPANSION}

The goal of the Protocol Amending the TRIPS Agreement (TRIPS Public Health Amendment) is to provide cheaper versions of patented medicines to underdeveloped and developing countries to address public health problems, ${ }^{43}$ thus providing the world's poorest people with better access to medicines. In certain situations, the TRIPS Public Health Amendment allows member countries of TRIPS who have insufficient manufacturing capacity to import patented pharmaceuticals made under a compulsory license from other member countries. ${ }^{44}$ This allows for cheaper versions of patented medicines that are needed to address public health problems, such as HIV/AIDS and malaria, by creating an exception to Article 31(f) of the TRIPS Agreement. ${ }^{45}$ Article 31(f) states that the production of pharmaceutical products under compulsory licenses must be predominantly supplied for the domestic market, which hinders the import of such pharmaceuticals to countries that are unable to produce them. ${ }^{46}$ The exception determines that a supply does not have to be predominantly for the domestic market, thus allowing the exportation of generic drugs, which are more affordable and more accessible for underdeveloped countries and their citizens. ${ }^{47}$

\section{ACCESS To ESSENTIAL MEDICINES}

The right to health has long been recognized in international human rights treaties. ${ }^{48}$ The World Health Organization (WHO) defined health as a "state of

40. Folsom, supra note 4, at 33 .

41. Id.

42. Hoen, supra note 2, at 52; see also, Margo A. Bagley, Legal Movements in Intellectual Property: TRIPS, Unilateral Action, Bilateral Agreements, and HIV/AIDS, 17 EMORY INT'L L. REV. 781, 787 (2003).

43. Protocol Amending the TRIPS Agreement, Report, 68 (2006), http://www.google.com/ url? $\mathrm{sa}=\mathrm{t} \& \mathrm{rct}=\mathrm{j} \& \mathrm{q}=\&$ esrc $=\mathrm{s} \&$ source $=$ web $\& \mathrm{~cd}=1 \& \mathrm{ved}=0 \mathrm{CB} 8 \mathrm{QFjAA} \& u r \mathrm{l}=\mathrm{http} \% 3 \mathrm{~A} \% 2 \mathrm{~F} \% 2 \mathrm{Fw}$ ww.aph.gov.au\%2FParliamentary_Business\%2FCommittees\%2FHouse_of_Representatives_Co mmittees\%3Furl\%3Djsct\%2F9may2007\%2Freport\%2Fchapter9.pdf\&ei=6tnzVKTNE5CvoQTp n4D4AQ\&usg=AFQjCNHrsb8vgUXOK-AWfYPPRK8qbo-6Fg\&bvm=bv.87269000,d.cGU.

44. Id.

45. Id.

46. Id. at 68-69.

47. Id. at 69 .

48. Patrick J. Wojahn, A Conflict of Rights: Intellectual Property under TRIPS, The Right 
complete physical, mental and social well-being and not merely the absence of disease and infirmity." ${ }^{49}$ Because of this broad definition of health, many United Nations (U.N.) bodies have interpreted the right to health to include a right to "available and accessible health care." ${ }^{50}$ The definition means that states must provide access to AIDS drugs. ${ }^{51}$ This requirement includes the specific: access to medical treatment and a prohibition against discrimination based on income. ${ }^{52}$

\section{A. The Right to Health in India}

India establishes the right to life as a fundamental right in Article 21 of its Constitution. ${ }^{53}$ The Indian Supreme Court has interpreted the right to life to also include a right to health. ${ }^{54}$ Some requirements of Article 21 include timely medical treatment and a right to protection of one's health while at work, which includes protection against sexual harassment. ${ }^{55}$

Novartis $A G v$. Union of India was the first case in India where a court explicitly recognized the constitutional right to health while interpreting patent law requirements. ${ }^{56}$ In 2006, the Patent Office in Madras rejected Novartis's patent application for Gleevac, a cancer drug. ${ }^{57}$ Novartis claimed that Gleevac was more effective than the previous cancer drug, Imatinib, because it increased absorption into the blood by $30 \%{ }^{58}$ However, the Assistant Controller determined that this $30 \%$ increase did not meet the enhanced efficacy requirement of $\S 3(\mathrm{~d})$ of the 2005 Patents Act and denied Novartis's patent application. ${ }^{59}$ Section 3(d) of the 2005 Patents Act defines "inventiveness" to determine patent eligibility. ${ }^{60}$

Novartis challenged $\S 3(d)$, arguing that it was unconstitutional under India's Equal Protection provision. ${ }^{6}$ Ultimately, the court did not find that $\S 3(\mathrm{~d})$ violated Article 14 of the Constitution, but did state that courts should consider access to affordable medicines as a component to the right to health and a relevant factor to be considered when determining the fate of a patent application. $^{62}$

to Health, and AIDS Drugs, 6 UCLA J. INT'L L. \& ForeIGN AFF. 463, 468 (2002).

49. Id.

50. Id. at 469 .

51. Id. at 473 .

52. Id.

53. Bazzle, supra note 25 , at 788 .

54. Id. at 789 .

55. Id.

56. Id. at 804; see also, Novartis AG v. Union of India, 2007 A.I.R. 24759 (MADRAS H.C.), available at $\mathrm{https}: / /$ indiankanoon.org/doc/266062/.

57. Id. at 803 .

58. Id. at 804 .

59. Bazzle, supra note 25 , at 804 .

60. Id. at 802 .

61. Id. at 804 .

62. Id. at 805 . 
Subsequent cases have relied on this reasoning and stressed the importance of the right to health in Indian patent law. ${ }^{63}$ For instance, the Delhi High Court rejected an injunction, sought by Roche, against an Indian manufacturer, Cipla. ${ }^{64}$ Roche was seeking the injunction because Cipla was producing Roche's patented anti-cancer drug Erlotonib. ${ }^{65}$ The court rejected the injunction because it would cause "irreparable injury" to the public and shorten lives if they were to stop Cipla's generic drug production. ${ }^{66}$ This was an "important extension of the reasoning in Novartis" in that this case focused on the right to health in resolving patent disputes. ${ }^{67}$ These cases illustrate that India's constitutional right to health will often trump India's post-TRIPS patent law.

\section{B. The Right to Health in South Africa}

South Africa has a very progressive constitution that guarantees the right to health care.$^{68}$ It states that the government must "take reasonable legislative and other measures, within its available resources, to achieve the progressive realization of each of these rights." ${ }^{69}$ However, South Africa's progressive constitution has caused some obstacles for the country. In 1999, South Africa was placed on the United States' Section 301 Priority Watch State List ("Watch List") because $\S 15(\mathrm{c})$ of the South Africa Medicines Act allowed the South African Minister of Health to take the necessary measures to protect the public health. ${ }^{70}$ The argument underlying this move was that South Africa was infringing on TRIPS and violating international intellectual property law. ${ }^{71}$ However, South Africa was removed from the Watch List later that year after South Africa "reaffirmed its obligations under TRIPS" and the United States agreed to help address South Africa's health problems. ${ }^{72}$ United States Trade Representative, Charlene Barshefsky, announced that she was removing South Africa from the "Watch List" because the South African government reaffirmed their objective, along with the United States', to "fully protec[t] intellectual property rights under the WTO TRIPS Agreement" and also address the health issues within South Africa. $^{73}$

63. Id.

64. Bazzle, supra note 25 , at 805 .

65. Id.

66. Id. at $805-806$.

67. Id.

68. Kwoka, supra note 30 , at 662 .

69. Id.

70. Winston P. Nagan, International Intellectual Property, Access to Health Care, and Human Rights: South Africa v. United States, 14 FlA. J. INT'L L. 155, 158 (2002).

71. Id.

72. Id. at n.14.

73. Press Release, Office of the U.S. Trade Representative, The Protection of Intellectual Property and Health Policy (Dec. 1, 1999), available at https://www.state.gov/documents/ organization/65893.pdf. 


\section{The Right to Health in Thailand}

Thailand covers a major part of its population with universal access to medicines through government organizations, including universal access to HIV/AIDS treatment. ${ }^{74}$ In 2004, Thailand introduced a healthcare plan funded by the government to provide basic health care to all Thai citizens. ${ }^{75}$ Additionally, the government pledged at Thailand's 15th International AIDS Conference to include HIV/AIDS patients in its new healthcare plan. ${ }^{76}$ This would include providing free medication to HIV/AIDS patients - an admirable, but potentially unattainable, goal. ${ }^{77}$ And hopes were high that Thailand could legitimately achieve its goal, however pharmaceutical patents were broken rather than using government money to fund healthcare for HIV/AIDS patients. ${ }^{78}$ Despite Thailand's commendable intention to support a universal health care system for its citizens and its position among the top 10\% wealthiest countries in the world, the government spends very little on health care - approximately $3.5 \%$ of its gross domestic product. ${ }^{79}$ While on the other hand, Cambodia and Lebanon spend near $12 \%$ on health care, and are much poorer countries in comparison. ${ }^{80}$

\section{TRIPS Conflicts with the Right to Health}

The TRIPS Agreement directly conflicts with the right to health because it includes such strict patent laws, and the requirement that binds each country to the GATT agreement. ${ }^{81}$ These strict patent protections drive up the price of HIV/AIDS drugs. ${ }^{82}$ This has forced a black market for drugs to emerge, particularly in Central America. ${ }^{83}$ The bottom line is that intellectual property rights cut off access to HIV/AIDS drugs for people that need them. ${ }^{84}$ Despite the role that patents have played in maintaining higher drug costs for public health programs across countries, this controversy has not led to a revision of TRIPS. Instead, the Doha Declaration was issued in November 2001 and higher drug costs have remained.

74. Frederick M. Abbott \& Jerome H. Reichman, The Doha Round's Public Health Legacy: Strategies for the Production and Diffusion of Patented Medicines Under the Amended TRIPS Provisions, 10(4) J. Int'1 Econ. L., 921, 952 (2007).

75. Stephanie Skees, Thai-ing Up the TRIPS Agreement: Are Compulsory Licenses the Answer to Thailand's AIDS Epidemic?, 19 PACE INT'L L. REV. 233, 238 (2007).

76. Id.

77. Id.

78. Id. at 239 .

79. Id. at 244 .

80. Id.

81. Wojahn, supra note 48 , at 475.

82. Id. at 485 .

83. Id. at 486 .

84. Id. 


\section{E. The Need for HIV/AIDS Drugs}

HIV/AIDS is a crisis not only domestically but also internationally. As of 2016, 36.7 million people were living with HIV or AIDS, with almost 25.6 million of those people living in the African region. ${ }^{85}$ In 2016, 1.0 million people died from HIV and 1.8 million people became infected, with two-thirds of the new HIV infections in the African region. ${ }^{86}$ Deaths are increasing every year and people infected are in need of urgent treatment. ${ }^{87}$ Because the HIV/AIDS pandemic is so concerning, the methods of treatment have gained global attention, ${ }^{88}$ as has the access to medicines that are needed to treat the disease or alleviate suffering. ${ }^{89}$ For instance, in 2006, the U.N. declared that their goal was to provide "universal access" to treatment by $2010 .{ }^{90}$ However, as of a 2009 report, while the access to medication was up from $33 \%$ to $42 \%$ in low and middle-income countries, these numbers remain well below the U.N.'s goal of universal access to medication. ${ }^{91}$ Considering that most people living with HIV/AIDS are concentrated in sub-Saharan Africa, one of the poorest regions in the world, generic, affordable options are vitally necessary. This need for generic drugs will be further examined in the later section discussing the efficacy of TRIPS in India.

\section{COMPULSORY LICENSES}

WTO members maintain significant policy options and flexibilities, including the freedom to issue compulsory licenses. Compulsory licenses are mechanisms that authorize the use of a patent protected by the government or a third party without the consent of the patent holder. ${ }^{92}$ Compulsory licenses may be issued on various grounds, including public health. ${ }^{93}$ Some countries, most notably Thailand, have developed strategies to use such compulsory licenses to reduce healthcare costs. ${ }^{94}$

However, a major limitation on compulsory license rules under Article 31(f) of TRIPS is the requirement that a product made under a compulsory license be

85. World Health Organization, HIV/AIDS Fact Sheet (2017), available at http://www.who.int/mediacentre/factsheets/fs360/en/.

86. Id.

87. Kwoka, supra note 30 , at 648

88. Id. at 650 .

89. Hoen, supra note 2, at 27.

90. Kwoka, supra note 30 , at 650.

91. World Health Organization, Towards Universal Access: Scaling up Priority HIV/AIDS Interventions in the Health Sector (2009), http://www.who.int/hiv/pub/2009progressreport/en/.

92. Dora Kripapuri, Reasoned Compulsory Licensing: Applying U.S. Antitrust's "Rule of Reason” to TRIP'S Compulsory Licensing Provision, 36 NEW ENG. L. REv. 669, 670 (2002).

93. Dianne Nicol \& Olasupo Owoeye, Using TRIPS Flexibilities to Facilitate Access to Medicines, Bulletin of the World Health Organization, Jul. 1, 2013, http:/dx.doi.org/ 10.2471/BLT.12.115865.

94. Id. 
supplied "predominantly to the licensee's domestic market." 95 This means that members with large markets, such as India, could easily grant compulsory licenses to supply patented medicines to meet public health needs. On the other hand, member countries with small markets, such as African countries, where AIDS is the most severe, might face a greater challenge in doing so. The problem within paragraph six is that many developing countries, such as African countries, lack the capacity to manufacture medicines on their own. ${ }^{96}$ Thus, the WTO is one agent that can grant compulsory licenses for the production and export of generic medicines to developing countries with insufficient manufacturing capacity in the pharmaceutical area. ${ }^{97}$ This is referred to as the "paragraph six solution" and was implemented in 2003. ${ }^{98}$

Despite this "solution" to paragraph six being implemented in 2003, paragraph six is used very infrequently. ${ }^{99}$ The reason is that obtaining a compulsory license is tedious because each time a product is produced, the process of obtaining a license has to restart. ${ }^{100}$ Further, there is no guarantee that the holders of the patent will not attempt to delay the process further. ${ }^{101}$ The President of a Canadian drug firm called Apotex accurately stated in a press release, "this process must change. . .to get quality affordable medicines to those who have no access." "102

The use of these options and flexibilities can help to increase accessibility to the supply of necessary medicines, thus allowing countries to have an appropriate balance between intellectual property protection and public health. One example being Zimbabwe, which declared a state of emergency for HIV/AIDS for six months in 2002 and allowed the government to authorize persons to "make or use any patented drug, including any antiretroviral drug" and to "import any generic drug used in the treatment ... of HIV/AIDS." 103

Similarly, India's patent laws allow the government to grant compulsory licenses. ${ }^{104}$ Under their provision, a third party can apply for a compulsory license

95. Carlos M. Correa, Implications of the Doha Declaration on the TRIPS Agreement and Public Health, World Health Organization (2002), available at http://apps.who. int/medicinedocs/pdf/s2301e/s2301e.pdf.

96. Divya Murthy, The Future of Compulsory Licensing: Deciphering The Doha Declaration on the TRIPS Agreement and Public Health, 17 AM. U. INT'L. L. REV. 1299, 1322 (2002).

97. Id.

98. WTO General Council, Implementation of Paragraph 6 of the Doha Declaration on the TRIPS Agreement and Public Health, Aug. 30, 2003, https://www.wto.org/english/tratop_e /TRIPS_e/implem_para6_e.htm.

99. Kaitlin Mara, Efficacy of TRIPS Public Health Amendment in Question at WTO, Intellectual Property Watch, Jan. 3, 2010, http://www.ip-watch.org/2010/03/01/efficacy-of-tripspublic-health-amendment-in-question-at-wto/.

100. Id.

101. Id.

102. Id.

103. Paul Hunt, Neglected Diseases: A Human Rights Analysis 36 (2007).

104. Poorvi Chothani, Intellectual Property Considerations in the Outsourcing Industry, 80 
under certain circumstances. Some circumstances include where the public requirements to health have not been satisfied or where a patented product is not available at an affordable price. ${ }^{105}$ Despite India's liberal compulsory license provisions, the country has rarely used them. ${ }^{106}$

One major issue is that many countries have yet to amend their laws to include such flexibilities because they do not agree with compulsory licensing. ${ }^{107}$ The Doha Declaration defines flexibilities in paragraph 5(a)-(d). Flexibilities include such things as the right to grant compulsory licenses and the right to determine "what constitutes a national emergency." 108 This can be detrimental to such countries' populations because some of these medicines are life-saving and are often needed in urgent situations.

\section{ISSUE: EFFICACY OF TRIPS PUBLIC HEALTH AMENDMENT}

There has been much criticism surrounding the TRIPS Protocol and its ability to achieve its goal of providing cheaper versions of patented medicines to underdeveloped and developing countries. Closely analyzing the effects of TRIPS in India, South Africa, and Thailand reveals that TRIPS has been more detrimental than successful in achieving its goal.

\section{A. India}

India is the leading producer of generic drugs, producing nearly $67 \%$ of exports. ${ }^{109}$ However, because of TRIPS intellectual property rights, India's ability to develop and manufacture generic drugs has become strained. ${ }^{110}$ Low-cost generic drugs are necessary alternatives to patented drugs for individuals who cannot afford expensive name brand drugs. ${ }^{111}$

The expanding international intellectual property rights (IPR) threaten to diminish generic medicine production. ${ }^{112}$ Before adopting TRIPS, India had a weak patent regime that promoted investment in the pharmaceutical industry. ${ }^{113}$ During this time, India was able to provide essential medicines to combat infectious diseases, as their generic medicine "infrastructure flourished."114 However, anxiety arose over the adoption of TRIPS because people worried that it would deprive the "most destitute" societies of essential affordable and high

APR N.Y. St. B.J. 30, 31 (2008).

105. Id.

106. Kripapuri, supra note 93 at 688.

107. See generally Id. at 692.

108. World Trade Organization, Declaration on the TRIPS Agreement and Public Health (2001), availableat, https://www.wto.org/english/thewto_e/minist_e/min01_e/mindecl_trips_e.htm.

109. Bazzle, supra note 25, at 785-86.

110. Id. at 785 .

111. Id. at 786 .

112. Id. at 787 .

113. Id.

114. Id. 
quality medicines. ${ }^{115}$ In 2002, India's pharmaceutical production was unregulated and they were able to provide a month's supply of antiretroviral medicine (AZT), for $\$ 48$, compared to the $\$ 239$ per month price in the United States. ${ }^{116}$ However, in 2005 , as intellectual property rights became stronger, anxiety continued to grow, as did the need for generic drugs. ${ }^{117}$

It is important that India has access to affordable drugs, especially considering they produce nearly $70 \%$ of generic drugs exports. Furthermore, India is a global supplier of antiretroviral drugs to regions that are most affected by HIV/AIDS. ${ }^{118}$ But the problem lies within the patent regime in India. The regime has threatened the future supply of generic antiretroviral drugs in India. ${ }^{119}$ Countries with the highest concentrations of HIV/AIDS do not have available technology to produce ARV drugs. ${ }^{120}$ The concentration of HIV/AIDS makes the need for generic versions of medicines in India critical, because these lessdeveloped countries depend on them to do so. ${ }^{121}$

When it comes to balancing strong IPR protections and the right to access affordable and essential medicines, the courts normally lean towards public health and the right to health rooted in India's Constitution. ${ }^{122}$ However, the TRIPS system in India does not grant the necessary flexibility to allow access to affordable essential medicines. ${ }^{123}$

\section{B. South Africa}

There has been visible conflict over essential medicines in Africa, particularly HIV/AIDS drugs. In February 1998, the South African Pharmaceutical Manufacturers Association and forty additional pharmaceutical manufacturers brought suit against the South African government, claiming that the Medicines and Related Substances Control Amendment Act No. 90 of 1997 violated TRIPS and the South African Constitution. ${ }^{124}$ The Act included a "legal framework" to increase the availability of affordable medicines in South Africa, including generic forms of patented medicines. ${ }^{125}$ Both the European Commission and the United States pressured South Africa to repeal the legislation. ${ }^{126}$ AIDS activists publicly shamed and embarrassed the United States' then-presidential candidate,

115. Bazzle, supra note 25.

116. Kripapuri, supra note 93, at 692.

117. Bazzle, supra note 25, at 787.

118. Edward Elgar, Intellectual Property and Sustainable Development: Development Agendas in a Changing World 129 (2009).

119. Id. at 130 .

120. Id.

121. Id.

122. Bazzle, supra note 25 , at $814-815$.

123. ElGAR, supra note 119, at 134-135

124. Hoen, supra note 2, at 43.

125. Id.

126. Id. at 44 . 
Al Gore, by criticizing his position. ${ }^{127}$ Eventually the outrage against the companies' challenge to the legislation weakened their legal position and they dropped the case in April 2001. ${ }^{128}$ This threat of legal action and political challenge against legislation would make any government wary to attempt to impose laws promising affordable, essential medicines.

As of 2006, an estimated 24.7 million people were living with HIV/AIDS in Sub-Saharan African countries. ${ }^{129}$ The price of drugs is a huge issue, especially in developing countries. It has been estimated that the average South African earns less than $\$ 3,000$ per year. ${ }^{130}$ Thus, many African countries have incorporated intellectual property protections in their domestic laws, including the granting of patent protection on medicines. ${ }^{131}$ Along with South Africa's progressive constitution, they also ratified the 1965 Medicines and Related Substances Control Act (Medicines Act) to parallel their progressive constitution. ${ }^{132}$ Under Section 22(f) of the Medicines Act, generic medicines would automatically be substituted when a brand-name prescription was to be filled. ${ }^{133}$ Further, an amendment of Section 15(c), "ensure[s] supply of more affordable medicines." 134 This section allowed for "lawful parallel importation . . . to protect the health of the public."135

However, there was a hostile response to the Medicines Act from the Clinton Administration. ${ }^{136}$ They were mostly concerned with the parallel importation provisions and sent a letter to Deputy President Thabo Mbeki of South Africa noting this concern. ${ }^{137}$ South Africa was later added to the United States government's "Watch List" under section 301 of the Patent Act. ${ }^{138}$ Eventually the United States government lessened its immense pressure on South Africa. ${ }^{139}$ However, in 1998, thirty-nine drug companies sued South Africa, challenging the law. ${ }^{140}$ Eventually the lawsuit was dropped and the companies admitted that the Medicines Act was lawful. ${ }^{141}$

A majority of African countries are also members of the WTO and are therefore required to adhere to its rules, specifically the patent protection of pharmaceuticals. These countries can use the waiver that was established by

127. Kwoka, supra note 30 , at 664 .

128. Hoen, supra note 2, at 43.

129. ElgAR, supra note 119, at 175.

130. Kripapuri, supra note 93, at 691.

131. Kwoka, supra note 30, at 662-63.

132. Id. at 662 .

133. Id. at 663 .

134. Id. (alteration in original).

135. Id. at 663 .

136. Id.

137. Id.

138. Kwoka, supra note 30, at 664.

139. Id.

140. Id.

141. Id. at 666 . 
implementation of paragraph 6 in the Doha Declaration in the 2003 Implementation Decision. ${ }^{142}$ The waiver allows for importation of essential medicines cheaply without the requirement of stringent patent protection. ${ }^{143}$ The waiver allows countries to export generic medicines to countries that otherwise would be incapable of doing so due to their manufacturing capabilities. ${ }^{144}$ The Doha Declaration clearly provides that the TRIPS Agreement "does not and should not prevent members from taking measures to protect public health and this could be interpreted and implemented in a manner supportive of WTO members' right to protect public health and, in particular, promote access to necessary medicines for all.", 145

Unfortunately, both the flexibilities of the Doha agreement and compulsory licensing have proven unsuccessful in South Africa. Despite the inclusion of a public health exception in TRIPS, patent protection has still prevented access to essential medicine. ${ }^{146}$ These flexibilities were underutilized in South Africa mainly because they were unclear and the government feared retaliation from other countries if they were to invoke them. ${ }^{147}$ For example, in 2001, when South Africa tried to implement the flexibilities for AIDS drugs (particularly compulsory licensing), forty-two pharmaceutical companies sued, alleging a violation of Article 27 of the TRIPS agreement. ${ }^{148}$ This forced the South African government to revert to normal patent protection, thus disallowing access to essential medicines and low costs for their population. ${ }^{149}$

Again in 2009, the so-called flexibilities of compulsory licenses failed South Africa. A South African generic manufacturer was prevented from exporting generic ARVs to four sub-Saharan countries before the registration of the ARVs had yet to occur - despite approval from the United States Food and Drug Administration (FDA). ${ }^{150}$ This meant that South Africa was unable to export generic versions of HIV/AIDS medicine to other countries with either none or insufficient manufacturing capacity. ${ }^{151}$ Countries that have the lowest level of manufacturing capabilities, such as South Africa, are heavily dependent on imports of finished drugs (including generics) to satisfy their health-care requirements. ${ }^{152}$ Thus, without access to generic drugs, South Africans are unable to obtain their right to healthcare as established in the Constitution.

142. Bhatt, supra note 144 , at 616 .

143. Id.

144. Id.

145. WHO, Doha Declaration on TRIPS Agreement and Public Health, adopted on Nov. 14, 2001, para. 4, http://www.wto.org/english/thewto_e/minist_e/min01_e/mindecl_TRIPS_e.htm.

146. Tina S. Bhatt, Amending TRIPS: A New Hope for Increased Access to Essential Medicines, 33 Brook. J. INT'L L. 597, 614 (2008).

147. Id.

148. Id.; see Bagley, supra note 42 at 784 .

149. Bhatt, supra note 143, at 614.

150. ElgAR, supra note 119, at 181.

151. Id.

152. Id. at 148 . 


\section{Thailand}

The United States has commenced free trade agreements (FTA) negotiations with many countries, including Thailand. ${ }^{153}$ In 2006, during the sixth round of FTA negotiations, the United States Trade Representative (USTR) submitted its draft of the IPR text to Thailand. ${ }^{154}$ The text included stricter provisions regarding compulsory licensing than those under TRIPS. ${ }^{155}$ The text obligated Thailand's drug regulatory authority to inform the patent holder when there was any attempt to register a generic drug. ${ }^{156}$ Further, the authority barred approval of a generic medicine unless it was certain that the generic would not infringe on patent rights of other companies. ${ }^{157}$ This ultimately imposed an unnecessary burden on both the drug authority and the entry of generic products into the market. ${ }^{158}$

Thailand realized there was a major issue with accessing vital medicines. In 2001 , in an attempt to remedy this problem, Thailand proposed a draft of a declaration on IPRs and public health. ${ }^{159}$ This draft eventually led to the adoption of the Doha Declaration on the TRIPS Agreement and Public Health. ${ }^{160}$

However, in 2007, Thailand, similarly to South Africa, suffered a public health crisis. ${ }^{161}$ Thailand issued compulsory licenses to produce the generic version of Kaletra, an AIDS medicine that was patented by Abbott Laboratories. ${ }^{162}$ Issuing the compulsory license would assist the Thai government in saving 8,000 lives. ${ }^{163}$ Abbott Laboratories refused to register the new drug because it stated that the Thai government was ignoring its patent protection. ${ }^{164}$ Manufacturing generic Kaletra cut Thailand off from accessing Kaletra and any of Abbott's other patented drugs. ${ }^{165}$ This is just one issue that countries face when trying to use flexibilities such as compulsory licensing. Countries, such as Thailand and South Africa, often also face the threat of trade sanctions or corporate litigation from pharmaceutical companies and Western governments. ${ }^{166}$ These obstacles frequently deter countries from attempting to issue compulsory licenses and then these countries fail to obtain essential medicines necessary to

153. Id. at 141 .

154. Id. at 143 .

155. Id. at 144 .

156. Id. at 145.

157. ELGAR, supra note 119.

158. Id.

159. Id. at 164 .

160. Id.

161. Kwoka, supra note 30, at 667.

162. Id.

163. Id.

164. Id.

165. Id.

166. Lisa Forman, Trade Rules, Intellectual Property, and the Right to Health, ETHICS \& INT'L AFF., 337, 342 (2007). 
aid in epidemics.

\section{CONCLUSION}

The pharmaceutical industry has produced hundreds of life-saving drugs. However, patents and the TRIPS Public Health Amendment often protect these drugs. As of 2003, this left approximately one-third of the world population without access to the most basic essential drugs and, in Africa and Asia, approaching one-half of the population. ${ }^{167}$ "Product-patent regimes" determine whether developing countries, particularly India, can successful comply under TRIPS. ${ }^{168}$ It has been argued that, on the one hand, a "product-patent regime" encourages innovation in developing countries. On the other hand, it severely undermines the ability of generic industries to grow. ${ }^{169}$ This type of regime arguably makes "public health more expensive" and also pushes public health away from the poorest citizens living in developing countries who need it the most. ${ }^{170}$

It seems that the TRIPS Public Health Amendment has been more detrimental than successful in India, South Africa, and Thailand. It is necessary to provide for flexibilities within patent laws, which are simply not available under the TRIPS Public Health Amendment, so that pharmaceutical industries can develop and provide cheaper medicines. ${ }^{171}$ Ultimately, developing countries need to make sure that their TRIPS patent laws balance rights and obligations. This includes the obligation to ensure access to medicines at affordable prices, which should remain the purpose of a country's patent law system. This is not an option under the TRIPS Public Health Amendment, despite compulsory licenses and its other flexibilities.

Compulsory licenses are allowed under Article 31 of TRIPS in cases of national emergencies or extreme urgency. ${ }^{172}$ And while the Doha Declaration further identifies HIV/AIDS, malaria, and other epidemics as public heath crises, the section still does not otherwise provide much guidance. ${ }^{173}$ Despite Article 31, "[a]ccess to even the most basic" medicines in the least developed countries is poor. ${ }^{174}$ Prices for generic drugs for antiretroviral treatment are still too high for sustainable treatment for millions of people in need. ${ }^{175}$ Patent prices are too high for "second-line treatments, treatment for children, and many other essential

167. Hoen, supra note 2, at 28.

168. Anil Kumar Kanungo, Don't Trip-Up Public Health, FIN. EXPRESS, Mar. 14, 2014, http://www.financialexpress.com/archive/don-t-tripup-public-health/1233284/, [https://perma.cc/B7TZ-G6JZ].

169. Id.

170. Id.

171. ElGAR, supra note 119, at 134.

172. Skees, supra note 76 , at 272.

173. Id.

174. Id. at 278 .

175. AFRICAFOCUS, supra note 6, [https://perma.cc/L8YP-SHSA]. 
medicines." ${ }^{176}$ Further, "[m]any least developed countries still do not have" a basic patent system in place and "WTO members [were] not required to implement" such systems until 2016. ${ }^{177}$ Even in countries that have no patent protection, these countries still lack access to essential medicines. ${ }^{178}$ But more importantly, even in India, South Africa, Thailand, and other countries where patent protection is a relatively new concept, "there has been no significant impact on access to medicines." 179

While the protocol amending TRIPS had good intentions, it seems to have failed various countries, including India, South Africa, and Thailand. The issue of pharmaceutical drug affordability is a huge public and political concern. The increasing price of drugs is constantly denying people access to sometimes lifesaving medicines and it is simply not fair to deprive anyone of their constitutional rights to both health and healthcare. It seems that an additional amendment to TRIPS is in order. If this is not a viable option, then countries need to start making the compulsory licensing models more workable, implement strategies with minimal obligations on potential licensees, and importing countries to ensure better access to medicines under TRIPS flexibilities. Medicines are not simply commercial commodities. For some, they are basic human needs. Given the potential loss of life that may occur under TRIPS, something must be changed to ensure basic human rights. Countries have a duty to prevent such unreasonably high costs for access to essential medicines. At a minimum, TRIPS patent protections should be lessened to the extent necessary to ensure the basic fundamental right to health.

176. Id.

177. Skees, supra note 76 , at 278.

178. Id.

179. Id. 